Nr 1(64), 2020, s. 21-36

https://doi.org/10.12797/Politeja.17.2020.64.02

\author{
Kazimierz Michał UJAZDOWSKI (D) \\ Uniwersytet Łódzki \\ kmujazdowski@gmail.com
}

\title{
ORYGINALNOŚĆ I TRWAŁOŚĆ V REPUBLIKI FRANCUSKIEJ
}

\section{ABSTRACT Originality and Permanence of the French Fifth Republic}

The case of the Fifth Republic encourages reflection on comparative constitutionalism both because of the originality of de Gaulle's constitutional work and the fact that during its validity the 1958 Constitution had to face new challenges - a change in the balance of political powers, European integration and the growth of the judiciary. The last two trends were universal in nature. The Fifth Republic proved an original and permanent constitution, giving the French democracy stability and efficiency. The constitutional system has not evolved either towards parliamentarianism or a presidential system like that of the USA. If there were significant amendments to the constitution, this happened in the area of external challenges. But also, in this area, where the constitutional judiciary became more dynamic and the guarantee of independence of the common judiciary increased, the Fifth Republic retained its originality, expressing the specificity of the French legal tradition.

Key words: de Gaulle, The French Fifth Republic, constitutional judiciary, reinforcement of sovereignty, constitutional thought

Słowa kluczowe: de Gaulle, V Republika Francuska, sądownictwo konstytucyjne, wzmocnienie suwerenności, myśl konstytucyjna 
$\mathrm{O}$ d chwili powstania V Republika wywoływała trudności interpretacyjne. Ustanowiony przez nią ustrój nie mógł być zakwalifikowany ani jako prezydencki, ani jako parlamentarny. Konstytucja z 1958 r. wprowadziła rozwiązanie hybrydowe, tworząc silną prezydenturę jako ośrodek przywództwa państwowego i zachowując parlamentarną odpowiedzialność rządu. V Republikę kwalifikowano jako system półprezydencki (Duverger ${ }^{1}$ ), prezydencjalny (Gicquel, Stembrowicz ${ }^{2}$ ), parlamentarny w opozycji do rządu zgromadzenia (Debré ${ }^{3}$ ), parlamentarny hiperzracjonalizowany $\left(\right.$ Larcher $\left.^{4}\right)$, a także ultraprezydencki (Duhamel ${ }^{5}$ ). Wydaje się, że najbliższy ujęcia specyfiki francuskiej konstytucji jest Philippe Ardant, który kładzie nacisk na wzmocnioną dwugłową egzekutywę ${ }^{6}$ V Republika dokonała bowiem kompleksowego wzmocnienia państwa, obejmującego nie tylko ustanowienie silnej prezydentury. Wolno sądzić, że zawdzięcza swoją oryginalność połączeniu dwóch koncepcji: sprawowania przywództwa państwowego przez prezydenta i wzmocnienia całej władzy wykonawczej przez instrumentarium zracjonalizowanego parlamentaryzmu. Obie wizje zostały klarownie wyłożone. Charles de Gaulle w przemówieniu wygłoszonym w 1946 r. w Bayeux przedstawił koncepcję powierzenia przywództwa państwowego prezydentowi znajdującemu się ponad podziałami politycznymi, dysponującemu prerogatywami osobistymi i jednocześnie będącemu zwierzchnikiem całej egzekutywy ${ }^{7}$. Michel Debré w przemówieniu na forum Rady Stanu w sierpniu 1958 r. kładł nacisk na instytucje, które stanowić będą podstawę rządnej demokracji parlamentarnej i dążył do wyposażenia premiera i rządu w instrumentarium pozwalające na efektywne rządzenie oraz dyscyplinowanie większości parlamentarnej ${ }^{8}$.

To hybrydowe rozwiązanie ustanowiło nowe reguły konstytucyjne ze skutkami w postaci wprowadzenia indywidualnego przywództwa państwowego, wyposażenia władzy wykonawczej w ponadprzeciętne instrumentarium i radykalnej odmiany zasad rywalizacji politycznej.

Wskutek rozwiązań przyjętych przez V Republikę Francja nie tylko nie wróciła do rządów parlamentarno-gabinetowych, lecz także wytworzyła niezwykle silne gwarancje stabilności i efektywności rządów. Ustanowienie silnej prezydentury (od 1962 r. mającej mandat z wyborów bezpośrednich) zagwarantowało prezydentowi podmiotowość

Les régimes semi-présidentiels, red. M. Duverger, Paris 1986.

2 J. Gicquel, Droit constitutionnel et institutions politiques, Paris 2001; J. Stembrowicz, Rzad w systemie parlamentarnym, Warszawa 1982, s. 168; tenże, Systemy polityczne wybranych państw kapitalistycznych. Francja, Warszawa 1977.

3 M. Debré, Przemówienie przed Radą Stanu, 27 sierpnia 1958 r., [w:] K.M. Ujazdowski, V Republika Francuska. Idee, konstytucja, interpretacje, Kraków 2010, s. 225-247.

4 G. Larcher, P. Bas, Réforme constitutionnelle. Un débat toujours recommencé, „Revue des deux mondes” 2017, kwiecień.

5 O. Duhamel, Droit constitutionnel et politique, Paris 1993, s. 69-70, Science Politique.

6 P. Ardant, Institutions politiques et droit constitutionnel, Paris 2000.

7 Ch. de Gaulle, Przemówienie w Bayeux, [w:] K.M. Ujazdowski, VRepublika Francuska..., s. 76-87.

$8 \quad$ M. Debré, Przemówienie przed Radą Stanu... 
$\mathrm{w}$ relacjach z partiami politycznymi. Jednocześnie stał się on rzeczywistym szefem władzy wykonawczej. Ustanowienie silnej prezydentury nie przyniosłoby konstytucyjnego efektu, gdyby nie mechanizm zracjonalizowanego parlamentaryzmu, tworzący szerokie pole dla prawodawstwa rządowego (rozporządzenia z mocą ustaw i możliwość uzyskania upoważnień do wydawania ordonansów) oraz dający władzy wykonawczej silne instrumenty w procesie stanowienia prawa w parlamencie i uchwalania budżetu. Całość konstrukcji uzupełniło większościowe prawo wyborcze, skutkujące konsolidacją systemu partyjnego i nadzwyczajnym instrumentem w rękach premiera, który pozwala na dyscyplinowanie większości parlamentarnej (art. 49-3 konstytucji). Wprowadzenie instytucji z dwóch porządków: logiki de Gaulle’a i logiki Debrégo dało bardzo wysokie gwarancje stabilności i efektywności rządzenia. Wydaje się, że wciąż aktualna jest opinia Raymonda Arona, który zauważył, że prezydent Francji dysponuje największą władzą spośród przywódców państw Zachodu?.

W latach 60. de Gaulle nie był pewny trwałości V Republiki. Uważał ponowne uzależnienie władzy politycznej od zmiennej gry partii i ośrodków politycznych za najpoważniejsze niebezpieczeństwo, któremu należy się przeciwstawić. Dał temu wyraz w czasie słynnej konferencji prasowej w 1964 r., podczas której mówił o zwolennikach rządu parlamentarnego dążących do tego, by partie mogły na nowo decydować o powotaniu premiera, sktadzie i wymianie gabinetu ${ }^{10}$. Przypomnieć wypada, że w latach 60. podejmowano próby znowelizowania konstytucji w kierunku zarówno parlamentarnym, jak i prezydenckim na wzór amerykański ${ }^{11}$. Twórca $V$ Republiki przeciwstawiał się obu dążeniom i podkreślał, że amerykanizacja systemu konstytucyjnego zablokuje mechanizm funkcjonowania państwa (konkurencja dwóch większości), a ścisłe rozdzielenie obu władz uzależni parlament i stanowienie prawa od zmiennej konstelacji partii politycznych.

V Republika okazała się konstrukcją trwałą i nie przeszła ewolucji, która mogłaby zakwestionować jej oryginalność za cenę dostosowania się do typowych modeli konstytucyjnych. Prezydent i podległy mu rząd zachowali duży zakres decyzyjności i zarazem podmiotowość wobec zaplecza politycznego. Dzięki mechanizmowi konstytucyjnemu nie dochodzi do parlamentaryzacji systemu konstytucyjnego i osłabienia władzy wykonawczej nawet wówczas, gdy sprzyja temu struktura obozu władzy, jak w okresie prezydentury François Hollanda. Jej możliwości były wydatnie ograniczane przez wewnętrzne rozbicie francuskiej lewicy.

Praktyka ustrojowa konstytucji V Republiki uwidacznia jej wewnętrzną elastyczność i różnorodność zastosowań, żadne jednak nie wiązało się z utratą podstawowych przymiotów, jakimi są stabilność i decyzyjność władzy wykonawczej. V Republika w pierwszym okresie funkcjonowania doświadczyła prezydencjalizmu absolutnego, którego

9 R. Aron, Esej o wolnościach, przeł. M. Kowalska, Warszawa 1997, s. 145-146, Biblioteka Polityczna "Aletheia", t. 4.

10 Ch. de Gaulle, Deklaracja na temat roli Prezydenta Republiki, [w:] K.M. Ujazdowski, V Republika Francuska..., s. 327.

11 C. Bigaud, Le réformisme constitutionnel en France (1789-2000), Paris 2000. 
koncepcja została wyłożona przez jej założyciela podczas słynnej konferencji prasowej w styczniu 1964 r. Twórca V Republiki nazywał prezydenta jedynym dysponentem wtadzy panstwowej i jedyna osoba wtadna ja delegowaćn ${ }^{12}$. W opinii de Gaulle'a władza prezydenta, mającego legitymację $\mathrm{z}$ wyborów powszechnych, miała charakter niepodzielny, a o nadaniu i utrzymaniu każdej innej władzy - rządowej, cywilnej, wojskowej i sądowniczej - decydował prezydent ${ }^{13}$. De Gaulle ignorował zarówno odrębny status konstytucyjny rządu określony w art. 20, jak i odrębny status władzy sądowniczej. Ten model prezydentury mógł kontynuować Georges Pompidou, choć w złagodzonej wersji. W opinii Oliviera Duhamela o modelu prezydencjalizmu absolutnego można mówić również w przypadkach tych okresów prezydentury François Mitterranda i Jacques’a Chiraca, kiedy dysponowali oni stabilną większością parlamentarną.

Po śmierci Pompidou praktyka ustrojowa Francji wielokrotnie odbiegała od interpretacji twórcy V Republiki. Nowa konstytucja musiała zmierzyć się z doświadczeniem prezydentury Valéry'ego Giscarda d'Estaing, który - w przeciwieństwie do swoich poprzedników - nie dysponował silnym poparciem większości parlamentarnej. Prezydent znajdował się w mniejszości w większości prezydenckiej, dlatego określał praktykę ustrojową w tym czasie jako model prezydentury zracjonalizowanej ${ }^{14}$. W podobnej sytuacji znalazł się Mitterrand w latach 1988-1993. W latach 70. XX w. jednoznacznie popierający prezydenta Giscarda d'Estaing liberalni centryści byli słabszym od gaullistów komponentem obozu prezydenckiego. Realna pozycja prezydenta uległa dodatkowemu osłabieniu po rezygnacji w $1976 \mathrm{r}$. Chiraca ze stanowiska premiera i założeniu Zgromadzenia na Rzecz Republiki, które stało się nowoczesnym i zdyscyplinowanym narzędziem polityki gaullistowskiej. Wypada podkreślić, że w czasie prezydentury Giscarda d'Estaing wzrosło znaczenie instytucji składających się na zracjonalizowany parlamentaryzm. Rząd Raymonda Barre’a kilkakrotnie posłużył się unikatowym w skali europejskiej przepisem z art. 49-3, pozwalającym na uchwalenie ustaw bez głosowania. W ten sposób np. przyjęto w czerwcu 1977 r. ustawę o bezpośrednich i powszechnych wyborach do Parlamentu Europejskiego, kwestionowaną przez istotną część starych gaullistów, z Debrém na czele ${ }^{15}$.

Istotnym sprawdzianem żywotności $\mathrm{V}$ Republiki było trzykrotne doświadczenie koabitacji (1986-1988, 1993-1995, 1997-2002). Także wówczas mechanizm konstytucyjny gwarantował wysoki stopień „decyzyjności” władzy wykonawczej, skoncentrowanej w tym wypadku w rękach premiera. Według mnie decydujące znaczenie miały fakt, iż konstytucja świadomie obniżyła ryzyko konfliktu pomiędzy dwoma członami

12 Ch. de Gaulle, Deklaracja generata de Gaulle'a na temat roli Prezydenta Republiki. Konferencja prasowa zdnia 31.01.1964, [w:] K.M. Ujazdowski, V Republika Francuska..., s. 323-331.

13 Interpretując praktykę ustrojową de Gaulle’a, Vedel twierdził, że prezydent podzielił obszar kompetencji na „sferę zachowaną” i „sferę delegowaną”. Nie może być wątpliwości, że tak szeroki zakres władzy prezydenta nie miał podstaw w normach konstytucyjnych. G. Vedel, Vers le Régime Présidentiel?, „Revue française de science politique” 1964, Vol. 14, nr 1.

14 O. Duhamel, Droit constitutionnel..., s. 39.

15 Zob. wystąpienia premiera Barre’a i Debrégo na forum Zgromadzenia Narodowego. M. Mopin, Les grands débats parlementaires. De 1875 à nos jours, Paris 1988, s. 191-201. 
władzy wykonawczej (brak weta prezydenta, niemożliwość użycia referendum jako narzędzia sporu między prezydentem i premierem) oraz nade wszystko wyposażenie premiera w instrumentarium sprzyjające efektywności rządzenia. Po wyborach w 2007 r. praktyka ustrojowa V Republiki ukazywała nadal różnorodność zastosowań. Prezydenturę Sarkozy'ego cechowały wyjątkowa aktywność prezydenta i jego wejście na pole bieżącego rządzenia. Prezydentura Hollanda wróciła do partnerskiego traktowania premiera i płaciła cenę dekompozycji zaplecza politycznego. Stosowanie konstytucji przez Macrona można ocenić jako powrót do gaullistowskiej koncepcji prezydentury z silną kumulacją władzy w rękach prezydenta i wtórną rolą partii politycznych jako jej pasa transmisyjnego ${ }^{16}$. Wypada raz jeszcze podkreślić, że żadne z zastosowań V Republiki nie naruszało warunków brzegowych konstytucji określonych w 1958 r. Nie doszło ani do ewolucji w stronę rządów zgromadzenia, ani do prezydencjalizacji ustroju na wzór amerykański.

Również reforma z 2000 r., skracająca kadencję prezydenta do pięciu lat i łącząca ją z kadencją Zgromadzenia Narodowego, nie zmieniła zasadniczych reguł konstytucyjnych, choć z pewnością nie odpowiadała myśli założycieli $V$ Republiki. Niewątpliwie jej walorem jest ograniczenie ryzyka koabitacji. Innowacja nie doprowadziła jednak do amerykanizacji francuskiego systemu konstytucyjnego, która pociągałaby za sobą ryzyko w postaci zablokowania mechanizmu funkcjonowania państwa. Francja nadal zachowuje oryginalny model ustrojowy w postaci podwójnej egzekutywy i możliwości dystrybucji zadań między prezydentem a premierem. V Republika spełnia w wysokim stopniu kryteria stabilności i efektywności rządów.

Można sądzić, że ukształtowanie silnej prezydentury jako ośrodka przywództwa państwowego odpowiadało rozbudowanej strukturze państwa „nowoczesnego kapitalizmu" i spełniało oczekiwanie wysokiej profesjonalnej biurokracji ${ }^{17}$. Nie mniej istotna była intencja wzmocnienia państwa w relacjach zewnętrznych. De Gaulle i Debré nie ukrywali, że nowa konstytucja ma umożliwić rywalizację z wiodącymi państwami europejskimi, które dysponowały wobec niej przewagą w postaci dobrego systemu konstytucyjnego. Chodziło przede wszystkim o Zjednoczone Królestwo i Republikę Federalną Niemiec, która po uchwaleniu konstytucji z 1949 r. dawała wzór rządnej demokracji ${ }^{18}$. W latach 40 . de Gaulle wielokrotnie podkreślał, że rekonstrukcja silnego państwa jest koniecznością podyktowaną wymogami międzynarodowej rywalizacji. W twardym i niebezpiecznym świecie ${ }^{19}$ rywalizacji między Stanami Zjednoczonymi a Związkiem Radzieckim przy jednoczesnym osłabieniu Europy Francja $i$ Unia Francuska maja szansę na zachowanie swej niezależności, bezpieczeństwa i praw pod warunkiem, że państwo będzie zdolne ponieść w określonym kierunku ciężar niezachwianej odpowiedzialności $i^{20}$.

16 O. Duhamel, Macron ou l'illusion de la république gaullienne, „Pouvoirs” 2018, Vol. 166, nr 3.

17 P. Avril, Le gouvernement de la France, Paris 1969, s. 157.

18 Więcej zob. R. Rémond, Les droites en France, Paris 1982.

19 Ch. de Gaulle, Przemówienie w Bayeux..., s. 97.

20 Tamże. 
Wydaje się, że w większości prac poświęconych genezie i oryginalności V Republiki nie uwzględniono w dostatecznym stopniu konstytucyjnych konsekwencji szczególnego przywiązania de Gaulle’a do idei wzmocnienia suwerenności państwa i wyróżnionej, sprawczej roli Francji w integrującej się Europie. Respekt dla tych wartości i krytyka federalnych form integracji europejskiej miały istotny wpływ na treść regulacji konstytucyjnych. Chodzi nie tylko o wolę zasadniczego umocnienia państwa i wyposażenia prezydenta $\mathrm{w}$ instrumentarium pozwalające na prowadzenie polityki zagranicznej i obronnej. Motyw wzmocnienia suwerenności państwa przesądził o ustanowieniu prewencyjnej kontroli zobowiązań międzynarodowych i był autonomicznym czynnikiem utworzenia Rady Konstytucyjnej. Dla gaullistów niezwykle istotne okazało się doświadczenie związane z nieudanymi próbami poddania kontroli konstytucyjności traktatów ustanawiających Europejską Wspólnotę Obronną (EWO) i Europejską Wspólnotę Węgla i Stali (EWWiS) w okresie IV Republiki. Debré, bliski wspólpracownik de Gaulle’a, inicjował te działania w latach 50. XX w., dążąc do badania konstytucyjności traktatów europejskich przez Komitet Konstytucyjny. Stanowczo odrzucał interpretację art. 26 konstytucji IV Republiki, w myśl której prawo traktatowe miało mieć moc nadrzędną nie tylko w stosunku do ustaw zwykłych, lecz także wobec samej konstytucji. Polityk domagał się od rządu przedłożenia kwestii zgodności traktatu z konstytucją pod obrady Rady Stanu i postulował zainicjowanie postępowania przed Komitetem Konstytucyjnym. Bronił poglądu, że ewentualna ratyfikacja traktatu ustanawiającego EWO musi być poprzedzona zmianą konstytucji ${ }^{21}$. W czasie debaty na forum Rady Republiki kwestionował stanowisko większości klasy politycznej, która przyjmowała, że od chwili podpisania traktatu dyspozycje konstytucyjne i ustawowe muszą być podporządkowane jego aplikacji. W wystąpieniu na forum Rady Republiki Debré argumentowat:

Nie można zgodzić się na to, by dyspozycje konstytucyjne zostaty uchylone przez traktat, albowiem istota takiej decyzji jest to, że nie może byćzmodyfikowana inaczej niz przez procedure rewizji i w warunkach przez nia przewidzianych, traktat przyjęty więsszościa zwykta nie może być przeciwstawiany tekstowi konstytucji zaakceptowanej przez większość szeroka [majorité large] albo przez referendum ${ }^{22}$.

Kilka lat później, w lipcu 1957 r., Michel Debré złożył wraz z senatorem Léo Hamonem wniosek o zbadanie przez Komitet Konstytucyjny uchwalonej przez Zgromadzenie Narodowe ustawy dającej upoważnienie do ratyfikacji traktatów rzymskich. Wniosek wskazywał na niezgodność z konstytucją art. 189 traktatu ustanawiającego Europejską Wspólnotę Gospodarczą (EWG) i art. 161 traktatu ustanawiającego EWWiS, które przyznawały jej organom, Radzie i Komisji, prawo do podejmowania

$21[\ldots]$ ratyfikacja traktatu, który ma zastąić Konstytucję w niektórych jej częściach, może być zgodnie z prawem dozwolona jedynie, jeśli Konstytucja da organom odpowiedzialnym za przeprowadzenie ratyfikacji lub za udzielenie na nia zgody petnomocnictwo, by dokonać również rewizji ustawy zasadniczej. Podczas gdy przy obecnym ksztatcie Konstytucji konieczna jest uprzednia zmiana niektórych artykutów. S. Aromatario, La pensée politique et constitutionnelle de Michel Debré, Paris 2006, s. 230, Bibliothéque Constitutionnelle et de Science Politique, 127. 
wiążących decyzji w sferze prawodawstwa. W opinii Debrégo obie regulacje traktatowe naruszały art. 13 konstytucji, stanowiący, że prawo do uchwalania ustaw przysługuje wyłącznie parlamentowi ${ }^{23}$. Wniosek został odrzucony przez komisję regulaminową, w jej imieniu przyszły przewodniczący Senatu i kandydat na prezydenta w 1969 r. Alain Poher wskazywał, że Komitet Konstytucyjny podejmuje działanie wyłącznie w sytuacji, w której zachodzi kolizja stanowisk dwóch izb parlamentu ${ }^{24}$.

Traktaty rzymskie zostały ratyfikowane i weszły w życie z dniem 1 stycznia $1958 \mathrm{r}$. De Gaulle pogodził się ze skutkami tej decyzji. Po zdobyciu władzy powstrzymał dalszą integrację, stawiając na wspólne decyzje szefów państw ${ }^{25}$. Debré oceniał krytycznie te regulacje konstytucji z 1946 r., które nie pozwalałyby na skuteczną kontrolę zobowiązań międzynarodowych. Przypomnieć wypada, że konstytucja z 1946 r. otworzyła się na prawo międzynarodowe w formule niedającej jasności co do prymatu konstytucji. Stąd zdecydowano się na rozwiązanie, które nie tylko wyrażało idee nadrzędności konstytucji, lecz także ustanawiało silne gwarancje instytucjonalne. Prewencyjna kontrola zobowiązań międzynarodowych, sprawowana przez Radę Konstytucyjną przed uchwaleniem ustawy zezwalającej na ratyfikację traktatów, odpowiadała na wezwanie do umocnienia suwerenności państwa, w procesie integracji, w ramach Wspólnoty Europejskiej.

V Republika umocniła zwartość państwa i konsekwentniej niż jej poprzedniczka wdrożyła w życie kluczową dla porządku republikańskiego zasadę niepodzielności. W momencie uchwalenia konstytucji V Republika podtrzymała unitaryzm w wersji centralistycznej. Zachowała także zasadę, że dialog między organizacjami interesów odbywa się w ramach państwa i żadna $\mathrm{z}$ korporacji gospodarczych nie dysponuje uprawnieniami publicznymi. Tej zasadzie odpowiada formuła ustrojowa Komitetu Ekonomiczno-Społecznego. W logice umocnienia „zwartości” państwa mieściła się także zmiana ustrojowa $\mathrm{w}$ sferze wymiaru sprawiedliwości ze skutkiem w postaci redukcji wpływów partii politycznych i reprezentacji korporacji sędziowskiej. Francuska tradycja prawna żywiła obawę wobec „władzy sędziów” i odnosiła się z rezerwą do powiększania gwarancji niezależności sądownictwa. W tradycji republikańskiej sądownictwo traktowano jako funkcję państwa, nie zaś odrębną władzę o znaczeniu

\section{Tamże.}

24 Alain Poher (1909-1996) dorastał pod wpływem Emmanuela Mouniera, w czasie wojny był związany z ruchem oporu. Po II wojnie światowej polityk Ludowego Ruchu Republikańskiego. Krytyczny wobec polityki de Gaulle’a. W 1969 r. kandydował na urząd prezydenta Republiki. W latach 1969-1982 piastował stanowisko przewodniczącego Senatu. W 1971 r. w następstwie jego wniosku Rada Konstytucyjna wydała historyczne orzeczenie, tworzące materialną podstawę kontroli konstytucyjności ustaw.

25 Uwagi o polityce europejskiej de Gaulle'a zob. L. van Middelaar, Przejście do Europy. Historia pewnego poczatku, przet. R. Pucek, N. Borowska, Warszawa 2011, s. 79-98. Francuski historyk integracji europejskiej Charles Zorgbibe pisał, że przywódcy V Republiki coraz wyraźniej zaczęli podważać oba postulaty tworzacej się Europy, to znaczy wyższośc konstrukcji ponadnarodowych nad wspótpraca. międzypaństwowa oraz orientacje dyplomacji zachodnioeuropejskiej ku wspótpracy ze Stanami Zjednoczonymi w ramach wielkiej wspólnoty atlantyckiej. Ch. Zorgblibe, Historia integracji europejskiej, przeł. A. Górska, Łódź 1998, s. 67-68, Integracja Europejska. Monografie, 9. 
porównywalnym do władzy ustawodawczej i wykonawczej. Krytyczny opis tej tradycji znajdziemy w dokumentach Komitetu Bardoux, który postulował wzmocnienie statusu sądownictwa ${ }^{26}$.

Warto przypomnieć, że IV Republika wprowadziła istotny wyłom od założeń tej tradycji. Konstytucja z 1946 r. powołała do życia Najwyższą Radę Sądownictwa i wyposażyła ją w kompetencje decyzyjne kosztem władzy wykonawczej. Prezydent powoływał sędziów i prokuratorów na podstawie wniosku Rady. Co najważniejsze, Rada miała podmiotowy status ustrojowy wobec władzy wykonawczej i działała w składzie parlamentarno-korporacyjnym. W skład Rady wchodziło sześciu członków wybieranych przez Zgromadzenie Narodowe, czterech wybieranych przez instancje sądownicze i dwóch - przez prezydenta Republiki. W pamięci instytucjonalnej Najwyższej Rady Sądownictwa był to okres silnych wpływów samej korporacji sędziów ${ }^{27}$.

Model ten spotkał się ze zdecydowanym sprzeciwem de Gaulle’a jeszcze w okresie prac nad konstytucją IV Republiki ${ }^{28}$. V Republika zgodnie z jego poglądami przywróciła władztwo prezydenta i ministra sprawiedliwości nad wymiarem sprawiedliwości. Prezydent zobowiązany do ochrony wymiaru sprawiedliwości stanął na czele Najwyższej Rady Sądownictwa, a jej wiceprzewodniczącym z mocy prawa był minister sprawiedliwości z konstytucyjnym upoważnieniem do zastępowania prezydenta. Rada składała się z dziewięciu członków powoływanych przez prezydenta i miała wnioskować w sprawie powołania prezesa Sądu Kasacyjnego oraz prezesa Sądu Apelacyjnego, zaś w przypadku nominacji na zwykłe stanowiska sędziowskie formułowała opinie niewiążące ministra sprawiedliwości.

V Republika ukształtowała państwo ze wzmocnioną suwerennością i wewnętrznie „skoncentrowane”. Ten model konstytucyjny musiał skonfrontować się z wyzwaniami o ogólnoeuropejskim wymiarze: wzrostem pozycji sądownictwa i europeizacją prawa. $\mathrm{Na}$ tych polach doszło do najbardziej znaczących zmian ustrojowych ${ }^{29}$.

Wzrost pozycji sądów i utworzenie sądownictwa konstytucyjnego nadały nową treść konstytucjonalizmowi powojennej Europy. Wskutek kumulacji władzy politycznej w rękach większości parlamentarnej, rozrostu legislacji i wzrostu potęgi samego państwa stało się ono nieodzownym warunkiem poszanowania praw jednostki. Mauro Cappelletti w klasycznym tekście o konieczności i legitymacji sądownictwa konstytu-

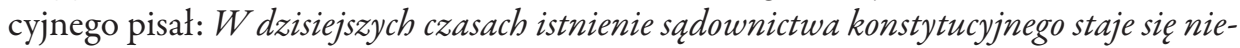
zbędne: równoważy ono duży i niepokojący wptyw wtadzy wykonawczej, jest nieuniknionym wynikiem ekspansji deklaracji praw ${ }^{30}$. Ponadto potrzebę ochrony praw jednostki przed nadużyciami ustawodawcy uzmysławiało doświadczenie totalitaryzmów.

26 J. Bardoux, France de demain. Son gouvernement, ses assemblées, sa justice, Paris 1936.

27 Genèse du Conseil supérieur de la magistrature, Conseil Superieur de La Magistrature, [online] http:// www.conseil-superieur-magistrature.fr/le-csm/histoire-et-patrimoine\#descr-140, 20 III 2019.

28 Ch. de Gaulle, Wystapienie w Epinal, [w:] K.M. Ujazdowski, VRepublika Francuska..., s. 96.

29 Wnikliwy opis nowelizacji konstytucji V Republiki Francuskiej zob. K. Kubuj, Zmiana konstytucji V Republiki Francuskiej. Przedmiot, tryb, kontrola, Warszawa 2018.

30 M. Cappelletti, Nécessité et légitimité de la justice constitutionnelle, „Revue internationale de droit comparé" 1981, Vol. 33, nr 2, s. 625-657. 
W przypadku Francji postulat kontroli konstytucyjności ustaw spotykał się ze sprzeciwem elity politycznej, a także republikańskiej doktryny prawnej. Ta uznawała parlament za jedyną instytucję legitymowaną do ekspresji suwerenności narodowej. Przyjmowano, że ustawa parlamentu nie może podlegać kontroli ze strony instytucji niemającej mandatu wywodzącego się z głosowania powszechnego. Doktryna stała na stanowisku, że ustawa z chwilą jej promulgacji staje się konstytucyjna. Ponadto specyficzny model zrośniętego z rządem sądownictwa administracyjnego i silna pozycja samej Rady Stanu, będącej w praktyce sądem konstytucyjnym w dziedzinie prawa administracyjnego, stanowily dodatkowy argument przeciw wprowadzeniu pełnowymiarowej kontroli konstytucyjności ustaw przez nową instytucję. We Francji istniały bardzo dobre powody, by nie wprowadzać Kelsenowskiego wzorca kontroli konstytucyjności prawa. Przemawiała przeciw niemu dbałość o pewność obowiązującego prawa Republiki, które nie może być kwestionowane przez instytucję niemającą mandatu z głosowania powszechnego. Nie mniej istotne były dualizm systemu prawnego i autonomiczne prawodawstwo rządowe, które nie pozwalało na wprowadzenie modelu Kelsena, zakładającego hierarchię aktów spójnego systemu prawnego.

W tej sytuacji zdecydowano się na rozwiązanie mieszczące się w ramach republikańskiej tradycji prawnej i odpowiadające politycznej motywacji reformatorów. W $1958 \mathrm{r}$. Rada Konstytucyjna została pomyślana jako część modelu zracjonalizowanego parlamentaryzmu. W trakcie prac nad projektem konstytucji propozycję powołania tej instytucji zgłoszono zaraz po zredagowaniu przepisów określających domenę ustawą ${ }^{31}$. Debré otwarcie mówil, że Rada Konstytucyjna powstała jako broń przeciw wypaczeniom ustroju parlamentarnego ${ }^{32}$. Konstytucja wprowadzała kontrolę prewencyjną inicjowaną jedynie przez prezydenta i przewodniczących obu izb. Jej przedmiotami mogły być wyłącznie ustawa uchwalona przez parlament i zobowiązanie międzynarodowe. Konstytucja zdecydowała, że w skład Rady wejdzie dziewięciu członków wybieranych na dziewięcioletnią kadencję oraz byli prezydenci Republiki, pełniący tę funkcję dożywotnio.

Warto też zwrócić uwagę na polityczny i „niesądowy” profil Rady Konstytucyjnej. Konstytucja poświęca jej osobny rozdział, niezwiązany z regulacjami odnoszącymi się do sądownictwa. Członkowie Rady Konstytucyjnej nie muszą spełniać kryterium wysokich kompetencji prawniczych. W praktyce składa się ona z przedstawicieli elity prawniczej i politycznej, z silnym udziałem tej ostatniej. Obecność byłych prezydentów Republiki podkreśla zaufanie konstytucji do przedstawicieli elity politycznej.

Zgodnie z przyjętymi założeniami w pierwszym okresie funkcjonowania Rada Konstytucyjna wydawała orzeczenia interpretujące restryktywnie zakres domeny

31 Zob. L. Noël, Comprendre de Gaulle, Paris 1972. Wypada odnotować, że ustanowienie Rady Konstytucyjnej spotkało się ze sprzeciwem René Cassina, wiceprzewodniczącego Rady Stanu. Zob. Compte rendu de la réunion du groupe de travail du 12 juin 1958 établi par M. François Luchaire, [w:] Documents pour servir à l'histoire de l'élaboration de la Constitution du 4 octobre 1958, Paris 1987, t. 1, s. 249. Podobnie Max Querrien kwestionował sens tej instytucji co do zasady, a Michel Aurillac wyraził pogląd, że jest uzasadniona tylko jako instytucja rozpatrująca zarzut niekonstytucyjności przedstawiany przez Radę Stanu lub Sąd Kasacyjny. Tamże, s. 382.

32 M. Debré, Przemówienie przed Radą Stanu..., s. 237. 
ustawowej, przyczyniając się tym samym do poszerzenia władzy reglamentacyjnej rzą$\mathrm{du}^{33}$. Trzeba zauważyć, że kontrola dotyczyła przede wszystkim ustaw uchwalonych przez parlament. A zatem poza zakresem kontroli Rady Konstytucyjnej znajdowały się akty prawotwórcze rządu, podlegające ocenie Rady Stanu, co dodatkowo wzmacniało pozycję władzy wykonawczej. Dodatkowo Rada Konstytucyjna kontrolowała obligatoryjnie zgodność z konstytucją regulaminów obu izb, co - jak wspominano - uznać należy za element francuskiego systemu zracjonalizowanego parlamentaryzmu. Można również sądzić, że Rada Konstytucyjna stała się kontrolerem aplikacji konstytucji wskutek obligatoryjnej kontroli konstytucyjności ustaw organicznych. Ponadto konstytucja z 4 października 1958 r. powierzyła jej kontrolę prawidłowości wyborów, co także trzeba uznać za wyraz pomniejszenia kompetencji parlamentu, który do tej chwili sam stwierdzał legalność wyborów. Wreszcie ograniczenie kręgu podmiotów inicjujących kontrolę do prezydenta, premiera i przewodniczących izb parlamentu zwracało Radę Konstytucyjną przeciwko nadużyciom parlamentu.

Jednakże już w latach 60 . Rada podjęła pierwsze decyzje, które sygnalizowały możliwość uzyskania przez nią silniejszej pozycji ustrojowej. Zdecydowała się wówczas na przeprowadzenie kontroli materialnej w orzeczeniu dotyczącym zgodności z konstytucją ustawy organicznej określającej status sędziów ${ }^{34}$. Zdynamizowanie sądownictwa konstytucyjnego wskutek dwóch reform podjętych w pierwszej połowie lat 70. XX w. i w 2008 r. słusznie uznawane jest za najpoważniejszą zmianę ustrojową po uchwaleniu konstytucji. W 1971 r. Rada Konstytucyjna wydała słynne orzeczenie tworzące podstawę materialnej kontroli konstytucyjności ustaw. Na podstawie tej decyzji blok konstytucyjny obejmował odtąd tekst konstytucji, Deklarację praw człowieka i obywatela z 1789 r. i preambułę do konstytucji IV Republiki. Gdy w 1974 r. prezydent Giscard d'Estaing spełnił zobowiązanie wyborcze i doprowadził do nowelizacji konstytucji dającej parlamentarzystom prawo inicjowania kontroli, droga do jej zdynamizowania została szeroko otwarta. Dało to początek bogatemu orzecznictwu, które rozwinęło ochronę praw jednostki.

W efekcie otwarcia kontroli materialnej i uniezależnienia kontroli od większości rządowej doszło do zasadniczego przekształcenia statusu Rady Konstytucyjnej, która uzyskała prestiż i podmiotowość właściwe silnym sądom konstytucyjnym. Jednakże wciąż francuski system kontroli konstytucyjności prawa zachowywał oryginalność podyktowaną sprzeciwem wobec kontroli następczej, szczególnie w wersji kontroli generalnej. W debacie konstytucyjnej traktowano ją jako przesunięcie władzy prawodawczej w ręce sądów, co pozostawało w sprzeczności z tradycją republikańską. Podnosił ten argument prezydent Sarkozy ${ }^{35}$. Jednocześnie w pracach eksperckich sygnalizowano ryzyko wprowadzenia chaosu i niepewności do systemu prawnego ${ }^{36}$. O podjęciu decyzji o wprowadzeniu w 2008 r. kontroli na podstawie zarzutu niekonstytucyjności

\footnotetext{
Zob. L. Garlicki, Rada Konstytucyjna a ochrona praw jednostki we Francji, Warszawa 1993, s. 21-22.

4 J. Stembrowicz, Parlament V Republiki Francuskiej, Warszawa 1963.

35 N. Sarkozy, Przemówienie w Epinal, [w:] K.M. Ujazdowski, V Republika Francuska..., s. 374.

P. Mazeau, Observation, [w:] E. Balladur, Une Ve République plus démocratique, Paris 2008, s. 191-195.
}

36 
w postępowaniu sądowym przeważyło uspójnienie kontroli konstytucyjnej z konwencyjną. Od momentu, gdy Francja ratyfikowała Europejską konwencję praw człowieka i obywatela, ujawniła się słabość kontroli konstytucyjnej na tle kontroli przeprowadzonej na podstawie zarzutu naruszenia konwencji prawa międzynarodowego. Strony procesów sądowych uzyskały prawo do kontroli konkretnej w bardzo szerokim zakresie przedmiotowym, podczas gdy w tych samych sprawach niemożliwa była kontrola konstytucyjności ustaw. Utrzymywanie tego stanu rzeczy oznaczało, że konstytucja nie funkcjonuje na bardzo wielu polach istotnych z punktu widzenia respektowania praw jednostki. Wraz ze wzrostem znaczenia prawa międzynarodowego i prawa europejskiego ta nieczynność konstytucji stawała się coraz bardziej paląca. Raport Balladura bardzo wyraźnie identyfikowal tę słabość: Rozszerzenie kontroli zgodności ustaw z obowiązującymi konwencjami międzynarodowymi, które w rozumieniu art. 55 Konstytucji francuskiej "mają moc wyższa niż ustawy”, pokazuje, że jedna i ta sama ustawa może być przedmiotem różnorodnych kontroli. Zatem każdy sędzia sądu powszechnego lub administracyjnego może, rozstrzygajac spór, wytaczyć stosowanie przepisu ustawowego, powotując się na jego niezgodność z umowa międzynarodowa, ale nie ma prawa uznać, że ten sam przepis jest sprzeczny z zasadami konstytucyjnymi. W pierwszym przypadku stosuje zasady w praktyce często podobne do zasad, które należatoby zastosować, jeżeli on sam lub Rada Konstytucyjna bytaby uprawniona do orzekania, czy promulgowana ustawa jest zgodna z Konstytucja. Z powyższego wynika, że strony sa sktonne większa wage przywiqzywać do norm prawa międzynarodowego niż do samej Konstytucji ${ }^{37}$.

Wprowadzenie ograniczonej i konkretnej kontroli następczej było najpoważniejszą zmianą ustrojową dokonaną w pięćdziesięciolecie uchwalenia konstytucji V Republiki Francuskiej. Reforma zachowała ostrożność i próbowała odpowiedzieć na przestrogi tych prawników, którzy zapowiadali sparaliżowanie systemu prawnego przez wnioski stron procesów sądowych. Podjęto więc decyzję, że uruchomienie procedury wymaga decyzji Sądu Kasacyjnego i Rady Stanu. Sama Rada Konstytucyjna ma prawo nierozpatrzenia wniosku, nowa instytucja nie jest zatem identyczna z typową skargą konstytucyjną. Wydaje się jednak, że praktyka ustrojowa wykroczyła poza założenia reformatorskie i doprowadziła do skokowego zwiększania ochrony praw jednostki.

Do poważnej ewolucji konstytucji doszło także w dziedzinie ustroju sądownictwa i prokuratury. Francja musiała odpowiedzieć na coraz silniejsze i powszechne w Europie oczekiwania środowisk prawniczych na ich podmiotowy udział w zasadniczych decyzjach dotyczących sądownictwa i prokuratury. Do istotnej zmiany doszło w 1993 r., gdy przeprowadzono nowelizację konstytucji na podstawie raportu Georges'a Vede$\mathrm{la}^{38}$. Raport opracowany pod jego auspicjami proponował przekazanie decyzji w sprawie nominacji sędziowskich w ręce Najwyższej Rady Sądownictwa o zrównoważonej reprezentacji. Ostatecznie nowelizacja konstytucji wprowadziła rozwiązanie nie tak

E. Balladur, Une Ve République..., s. 168-169.

38 G. Vedel, Rapport du 15 février 1993 remis au president de la republique le 15-02-1993 par le comite consultatif pour la revision de la constitution, „Journal Officiel de La République Française”, 16 II 1993, nr 39, s. 2537, [online] https://www.legifrance.gouv.fr/jo_pdf.do?id=JORFTEXT000000498419\&pageCourante=02537, 18 III 2019. 
radykalne, jak rekomendacje raportu. Rada uzyskała status instytucji współdecydującej, a w jej skład, podobnie jak w okresie IV Republiki, weszli przedstawiciele korporacji prawniczych.

Przypadek Francji jest interesujący ze względu na to, że w debacie konstytucyjnej i w samych zmianach w konstytucji uwidoczniają się kluczowe dylematy związane z rozmiarem gwarancji niezależności sądownictwa i dystrybucji kompetencji między władzą wykonawczą a reprezentacją korporacji sędziów i prokuratorów. V Republika przechodzi powolną ewolucję w stronę upodmiotowienia Naczelnej Rady Sądownictwa i zwiększenia udziału przedstawicieli sędziów i prokuratorów w realnym procesie decyzyjnym. Model ten zachowuje jednak wciąż silną pozycję władzy wykonawczej. Stąd także w tym przypadku można mówić o asertywności V Republiki. Wypada zauważyć, że w debacie konstytucyjnej otwarcie stawiany jest nie tylko problem zagrożeń dla niezależności sądownictwa ze strony władzy politycznej. Oba opracowane przez prawników raporty, które poprzedziły nowelizacje konstytucji w latach 1993 i 2008, identyfikowały zagrożenie korporatyzacji wymiaru sprawiedliwości. Raport Balladura sprzeciwił się także ustanowieniu niezależnego prokuratora Republiki ze względu na ryzyko wymknięcia się tej instytucji spod kontroli demokratycznej sprawowanej przez parlament ${ }^{39}$.

Europeizacja konstytucji i krajowego porządku prawnego stanowiła wyzwanie dla wszystkich państw członkowskich Wspólnoty Europejskiej i wraz z postępem integracji musiała prowadzić także do nowej interpretacji zasad konstytucyjnych i przewartościowania zasady suwerenności państwa. Jak wspomniano, V Republika wyrażała prymat konstytucji nad prawem międzynarodowym i wprowadzała w tej sferze specjalną procedurę kontrolną. Oznaczało to istotną różnicę w stosunku do konstytucji z 1946 r. Interpretacja przepisów konstytucji IV Republiki mogła przemawiać za nadrzędnością umów międzynarodowych nie tylko nad ustawami zwykłymi, lecz także nad samą konstytucją. W 1958 r. ustanowienie prewencyjnej kontroli zobowiązań międzynarodowych traktowane było jako wyraz rezerwy wobec pogłębiania integracji i silnej nieufności wobec instytucji ponadnarodowych. Eurosceptyczna interpretacja V Republiki była uzasadniona w świetle praktyki politycznej de Gaulle’a, który skutecznie powstrzymał proces integracji europejskiej. Warto przypomnieć, że w czasie jego prezydentury Francja nie ratyfikowała Europejskiej konwencji praw człowieka i obywatela, co wstrzymywało oddziaływanie prawa międzynarodowego na porządek krajowy.

Gdy Francja odstąpiła od polityki nieufności wobec Wspólnot Europejskich, instytucje konstytucyjne okazały się efektywne jako narzędzia aktywnego udziału we wspólnotach kontroli procesu integracji i dbałości o to, by odbywała się w ramach konstytucyjnych. Kontrola prewencyjna zastosowana w odniesieniu do traktatu z Maastricht legła u podstaw wprowadzenia do konstytucji rozdziału europejskiego wraz ze zdefiniowaniem samej UE jako dobrowolnej wspólnoty utworzonej przez państwa, które postanowity wspólnie wykonywać niektóre ze swych kompetencji. W kolejnych latach decyzje Rady Konstytucyjnej odnoszące się do nowych traktatów: traktatu z Amsterdamu, Konstytucji dla Europy i traktatów z Lizbony, a także do decyzji dotyczących

39 E. Balladur, Une Ve République..., s. 153-155. 
istotnych zobowiązań międzynarodowych (europejski nakaz aresztowania, Schengen), stanowiły podstawę nowelizacji rozdziału konstytucji o Unii Europejskiej ${ }^{40}$. Rada Konstytucyjna stosowała dwie ścieżki kontroli, obok kontroli prewencyjnej, w niektórych przypadkach badana była sama ustawa wyrażająca zgodę na ratyfikację, co dodatkowo wzmacniało kontrolę nad procesem integracji.

Rada Konstytucyjna wypracowała elastyczną formułę kontroli konstytucyjności traktatów, eksponując kryterium respektowania podstawowych warunków wykonywania suwerenności jako oceniające jakość kompetencji, których wykonywanie zostało przeniesione na UE, ich zakres i sposób przenoszenia ${ }^{41}$. W praktyce okazała otwartość wobec pogłębienia integracji, nie blokując zobowiązań traktatowych, włącznie z projektem Konstytucji dla Europy, który na podstawie decyzji Rady mógł być ratyfikowany pod warunkiem uprzedniej zmiany konstytucji. Jak wiadomo, traktat podpisany w Atenach został odrzucony w referendum. Niewątpliwym walorem prewencyjnej kontroli konstytucyjności traktatów europejskich jest usunięcie ryzyka obowiązywania pierwotnego prawa UE, które mogłoby pozostawać w sprzeczności z normami konstytucyjnymi, i nadanie wyraźnej legitymacji konstytucyjnej kolejnym aktom coraz ściślejszej integracji w ramach UE.

Trzeba też zauważyć, że dbałość o prymat konstytucji wyraża się również w kontroli konstytucyjności prawa wtórnego Unii Europejskiej. Uznając, że podlega ono kontroli, Rada Konstytucyjna wypracowała w trakcie jej orzekania pojęcie zasad nieodłącznie związanych z tożsamością konstytucyjną Francji. Regulacje prawa wtórnego mogą być uznane za niekonstytucyjne, gdy sprzeciwiają się zasadom fundamentalnym dla francuskiej tradycji prawnej ${ }^{42}$. Jednocześnie podjęto próbę wzmocnienia konstytucji na polu ochrony praw jednostki w relacji do prawa międzynarodowego, które odgrywało coraz silniejszą rolę w procesach sądowych. Jak wspomniano, jednym z sensów reformy z 2008 r. ustanawiającej kontrolę na podstawie zarzutu niekonstytucyjności w procesie sądowym była dbałość o prymat kontroli konstytucyjnej nad konwencyjną. Zamysł ten powiódł się w ograniczonym zakresie, albowiem w tej sprawie widoczna jest różnica

40 Europeizacja konstytucji państw cztonkowskich, red. K. Kubuj, J. Wawrzyniak, Warszawa 2011, s. 100-101.

41 S.-L. Formery, La Constitution commentée article par article, Lyon 2005, s. 852-897, Fondamentaux, 17.

427 VII 2006, Decyzja Rady Konstytucyjnej, 2006-540 DC. Ponadto przypomnieć wypada, że prawo do kontroli pierwotnego i pochodnego prawa wspólnotowego ma we Francji Rada Stanu ze względu na swoją wyjątkową pozycję jako sąd administracyjny najwyższej instancji. Po wprowadzeniu kontroli konstytucyjności ustaw na podstawie zarzutu niekonstytucyjności możliwa stała się także kontrola następcza prawa wspólnotowego, jest jednak za wcześnie na dokonanie pierwszego bilansu w tej sferze. Co ciekawe, przewodniczący Rady Konstytucyjnej Jean-Louis Debré stwierdził, że kontrola na podstawie zarzutu niekonstytucyjności zintegruje orzecznictwo Rady Stanu i Rady Konstytucyjnej w dziedzinie badania konstytucyjności prawa pochodnego UE. Zob. J.-L. Debré, Réflexions, [w:] D. Chagnollaud, Les 50 ans de la Constitution, 1958-2008, Paris 2008, s. 335-343. Zob. także prace o kontroli konstytucyjności prawa pochodnego UE: K. Wójtowicz, Glosa do orzeczenia francuskiej Rady Konstytucyjnej $z$ dnia 10 czerwca 2004 (sygn. 2004-496 DC), „Przegląd Sejmowy” 2005, nr 13; tegoż, Francuski model kontroli konstytucyjności prawa krajowego implementującego prawo wspólnotowe, [w:] Prawa cztowieka, spoteczeństwo obywatelskie, państwo demokratyczne, red. P. Tuleja, M. Florczak-Wątor, S. Kubas, Warszawa 2010; K. Kubuj, Opinia prawna na temat kontroli konstytucyjności prawa wtórnego Wspólnoty/Unii Europejskiej na przyktadzie Francji, Biuro Analiz Sejmowych, Warszawa 2011. 
między praktyką Rady Stanu, nastawionej na ochronę nadrzędności prawa krajowego, a Sądem Kasacyjnym, zorientowanym na kooperacje z Trybunałem Sprawiedliwości UE. We francuskiej debacie naukowej podnoszone są postulaty ograniczenia wpływu międzynarodowych instancji sądowych na krajowy porządek prawny przy wykorzystaniu instytucji konstytucyjnych ${ }^{43}$.

V Republika przyczynia się do zwiększenia efektywności polityki europejskiej Francji. Nie chodzi jedynie o stabilność i ciągłość polityki w UE, urzeczywistnioną dzięki wzmocnieniu prezydentury i całej władzy wykonawczej. Osobne znaczenie ma zachowanie samoistnego prawodawstwa rządowego, ponieważ dekrety z mocą ustaw stanowią kluczową formę implementacji dyrektyw, co pozwala podnieść jakość i spójność legislacji w tej sferze. Jednocześnie Francja utrzymała model obecności w UE oparty na zaufaniu do działań prezydenta i rządu z niewielkim udziałem innych aktorów, w tym instytucji samorządowych i partii politycznych. Pogląd, że konstytucja V Republiki zachowała swoją oryginalność, otwierając się na prawo europejskie, jest całkowicie usprawiedliwiony.

Konstytucja V Republiki zachowała swoją oryginalność, skutecznie kładąc kres Francji nierządzonej ${ }^{44}$. Przewodniczący Senatu Gérard Larcher zauważył, że za mglistą ideą VI Republiki kryje się zazwyczaj idea powrotu do rządów zgromadzenia, które osłabiały Francję przez siedem dekad ${ }^{45}$. Wydaje się jednak, że żadna z istotnych sił politycznych we Francji nie dąży do podważenia fundamentów konstytucji z $1958 \mathrm{r}$. Nie istnieje ryzyko parlamentaryzacji V Republiki. Nawet Marine Le Pen, znajdująca się w ostrej opozycji do klasycznych partii, respektuje założenia konstytucji. Można sądzić, że jej program w sprawach konstytucyjnych to wyraz powrotu do praktyki ustrojowej z okresu sprawowania władzy przez de Gaulle'a ${ }^{46}$. Kluczowe jest nie tylko zachowanie oryginalności i trwałości V Republiki, lecz także to, że nadal stanowi ona wariant rządnej demokracji z silnymi przesłankami stabilności i efektywności władzy. Korpus instytucjonalny V Republiki nie został zmieniony. Jeśli doszło do istotnych zmian konstytucji, to działo się to w obszarze nowych wyzwań. Również w tej sferze, w której nastąpiło zdynamizowanie sądownictwa konstytucyjnego i zwiększenie gwarancji niezależności sądownictwa, V Republika zachowała odmienność właściwą dla francuskiej tradycji prawnej.

\section{BIBLIOGRAFIA}

Ardant P., Institutions politiques et droit constitutionnel, Paris 2000.

Aromatario S., La pensée politique et constitutionnelle de Michel Debré, Paris 2006, Bibliothèque Constitutionnelle et de Science Politique, 127.

\footnotetext{
43 B. Mathieu, Le droit contre la démocratie?, Paris 2017.

44 G. Larcher, P. Bas, Réforme constitutionnelle...

45 Tamże.

46 M. Le Pen, Les 144 engagements présidentiels, [online] https://rassemblementnational.fr/le-projet-demarine-le-pen, 20 III 2019.
} 
Aron R., Esej o wolnościach, przeł. M. Kowalska, Warszawa 1997, Biblioteka Polityczna „Aletheia", 4.

Avril P., Le gouvernement de la France, Paris 1969.

Balladur E., Une Ve République plus démocratique, Paris 2008.

Bardoux J., France de demain. Son gouvernement, ses assemblées, sa justice, Paris 1936.

Bigaud C., Le réformisme constitutionnel en France (1789-2000), Paris 2000.

Cappelletti M., Nécessité et légitimité de la justice constitutionnelle, „Revue internationale de droit compare" 1981, Vol. 33, nr 2, https://doi.org/10.3406/ridc.1981.3285.

Compte rendu de la réunion du groupe de travail du 12 juin 1958 établi par M. François Luchaire, [w:] Documents pour servir à l'histoire de l'élaboration de la Constitution du 4 octobre 1958, t. 1, Paris 1987.

Debré J.-L., Réflexions, [w:] D. Chagnollaud, Les 50 ans de la Constitution, 1958-2008, Paris 2008.

Debré M., Przemówienie przed Radą Stanu 27 sierpnia 1958, [w:] K.M. Ujazdowski, VRepublika Francuska. Idee, konstytucja, interpretacje, Kraków 2010.

De Gaulle Ch., Deklaracja generata de Gaulle’a na temat roli Prezydenta Republiki. Konferencja prasowa z dnia 31.01.1964, [w:] K.M. Ujazdowski, V Republika Francuska. Idee, konstytucja, interpretacje, Kraków 2010.

De Gaulle Ch., Przemówienie w Bayeux, [w:] K.M. Ujazdowski, V Republika Francuska. Idee, konstytucja, interpretacje, Kraków 2010.

De Gaulle Ch., Wystapienie w Epinal, [w:] K.M. Ujazdowski, VRepublika Francuska. Idee, konstytucja, interpretacje, Kraków 2010.

Duhamel O., Droit constitutionnel et politique, Paris 1993, Science Politique.

Duhamel O., Macron ou l'illusion de la république gaullienne, „Pouvoirs” 2018, Vol. 166, nr 3, https://doi.org/10.3917/pouv.166.0005.

Europeizacja konstytucjipaństw Unii Europejskiej, red. K. Kubuj, J. Wawrzyniak, Warszawa 2011. Formery S.-L., La Constitution commentée article par article, Paris 2005, Fondamentaux, 17.

Garlicki L., Rada Konstytucyjna a ochrona praw jednostki we Francji, Warszawa 1993.

Genèse du Conseil supérieur de la magistrature, Conseil Superieur de La Magistrature, [online] http://www.conseil-superieur-magistrature.fr/le-csm/histoire-et-patrimoine\#descr-140.

Gicquel J., Droit constitutionnel et institutions politiques, Paris 2001.

Kubuj K., Opinia prawna na temat kontroli konstytucyjności prawa wtórnego Wspólnoty/Unii Europejskiej na przyktadzie Francji, Biuro Analiz Sejmowych, Warszawa, 15 II 2011.

Kubuj K., Zmiana konstytucji V Republiki Francuskiej. Przedmiot, tryb, kontrola, Warszawa 2018.

Larcher G., Bas P., Réforme constitutionnelle. Un débat toujours recommencé, „Revue des deux mondes" 2017, kwiecień.

Le Pen M., Les 144 engagements présidentiels, [online] https://rassemblementnational.fr/ le-projet-de-marine-le-pen/.

Les régimes semi-présidentiels, red. M. Duverger, Paris 1986.

Mathieu B., Le droit contre la démocratie?, Paris 2017, Forum.

Mazeau P., Observation, [w:] E. Balladur, Une Ve République plus démocratique, Paris 2008.

Mopin M., Les grands débats parlementaires. De 1875 à nos jours, Paris 1988. 
Noël L., Comprendre de Gaulle, Paris 1972.

Prawa cztowieka, spoteczeństwo obywatelskie, państwo demokratyczne. Ksiega jubileuszowa dedykowana profesorowi Pawtowi Sarneckiemu, red. P. Tuleja, M. Florczak-Wątor, S. Kubas, Warszawa 2010.

Rémond R., Les droites en France, Paris 1982.

Sarkozy N., Przemówienie w Epinal, [w:] K.M. Ujazdowski, V Republika Francuska. Idee, konstytucja, interpretacje, Kraków 2010.

Stembrowicz J., Parlament V Republiki Francuskiej, Warszawa 1963.

Stembrowicz J., Rząd w systemie parlamentarnym, Warszawa 1982.

Stembrowicz J., Systemy polityczne wybranych państw kapitalistycznych. Francja, Warszawa 1977. Ujazdowski K.M., V Republika Francuska. Idee, konstytucja, interpretacje, Kraków 2010.

Van Middelaar L., Przejście do Europy. Historia pewnego początku, przeł. R. Pucek, N. Borowska, Warszawa 2011.

Vedel G., Rapport du 15 février 1993 remis au president de la republique le 15-02-1993 par le comite consultatif pour la revision de la constitution, „Journal Officiel de La République”, 16 II 1993, nr 39, [online] https://www.legifrance.gouv.fr/jo_pdf.do?id=JORFTEXT 000000498419\&pageCourante $=02537$.

Vedel G., Vers le Régime Présidentiel?, „Revue française de science politique” 1964, Vol. 14, nr 1, https://doi.org/10.3406/rfsp.1964.403410.

Wójtowicz K., Francuski model kontroli konstytucyjności prawa krajowego implementującego prawo wspólnotowe, [w:] Prawa cztowieka, spoteczeństwo obywatelskie, państwo demokratyczne. Ksiega jubileuszowa dedykowana profesorowi Pawtowi Sarneckiemu, red. P. Tuleja, M. Florczak-Wątor, S. Kubas, Warszawa 2010.

Wójtowicz K., Glosa do orzeczenia francuskiej Rady Konstytucyjnej z dnia 10 czerwca 2004 (sygn. 2004-496 DC), „Przegląd Sejmowy” 2005, nr 13.

Zorgblibe Ch., Historia integracji europejskiej, przeł. A. Górska, Łódź 1998, Integracja Europejska. Monografie, 9.

Dr hab. Kazimierz M. UJAZDOWSKI, prof. UŁ - dr hab. nauk prawnych, profesor nadzwyczajny Uniwersytetu Łódzkiego. Twórca Europejskiego Centrum Badań Ustrojowych przy Wydziale Prawa i Administracji UŁ. W pracy naukowej specjalizuje się w dziedzinie doktryn politycznych i prawa konstytucyjnego. Szczególne przedmioty zainteresowania to: wpływ idei politycznych na rozwiązania konstytucyjne, tożsamość konstytucyjna państw, polska i francuska myśl polityczna XX w. i efektywność władzy politycznej w warunkach demokracji parlamentarnej. Były poseł na Sejm, wicemarszałek Sejmu, dwukrotnie sprawował funkcję ministra kultury (2000-2001, 2005-2007). Były poseł do Parlamentu Europejskiego, obecnie Senator RP. Autor m.in. publikacji: Żywotność konserwatyzmu. Idee polityczne Adolfa Bocheńskiego (2005), V Republika Francuska. Idee, konstytucja, interpretacje (2010), Geneza i tożsamość Konstytucji V Republiki Francuskiej. Studium doktrynalno-prawne (2013). 